\title{
Typification of Opuntia australis (CACTACEAE) WITH an ORIGINAL PLATE FROM 1882 AND HISTORY OF THE PLANT'S FINDING
}

\author{
TipificACIÓn de OPUntia AUSTRALIS (CACTACEAE) CON UNA LÁMINA \\ ORIGINAL DE 1882 E HISTORIA DEL HALLAZGO DE LA PLANTA
}

\author{
Roberto Kiesling ${ }^{1 *}$, Jean-René Catrix ${ }^{2}$, Florence Tessier ${ }^{3}$ and Daniel Schweich ${ }^{4}$
}

1. Member of the Carrera del Investigador Científico, IADIZA CONICET, Mendoza.

2. Cactophile, Éragny sur Oise, France.

3. Librarian at the botany library, Direction des Bibliothèques et de la Documentation, Muséum National d'Histoire Naturelle, Paris, France.

4. Retired from CNRS, Jonage, France

*rkiesling@mendoza.conicet.gob.ar

\section{Citar este artículo}

KIESLING, R., J. R. CATRIX, F. TESSIER \& D. SCHWEICH. 2021. Typification of Opuntia australis (Cactaceae) with an original plate from 1882 and history of the plant's finding. Bol. Soc. Argent. Bot. 56: 45-54.

DOI: https://doi.org/ 10.31055/1851.2372.v56.n1.30584

Recibido: 19 Oct 2020

Aceptado: 26 Feb 2021

Publicado en línea: 8 Mar 2021

Publicado impreso: 31 Mar 2021

Editor: Roberto Manuel Salas (D)

ISSN versión impresa 0373-580X

ISSN versión on-line 1851-2372

\section{SUMMARY}

The neotypification of Opuntia australis F.A.C.Weber, basionym of Pterocactus australis (F.A.C.Weber) Backeb., is made here thanks to the discovery of Weber's personal notes about it, and of two notebooks containing respectively a drawing and a short description of that plant, both made at the time of its first collection in 1882. Outlined as well is the poorly documented scientific expedition that made this first discovery and the cultivation of an early plant by F.E. Schlumberger on Weber's behalf. A Weber's note confirms he knew the mentioned illustration. A herbarium specimen from the same gathering has been found, but it cannot be considered original material since there is no evidence that it was seen by Weber. However, this specimen is here designated as epitype.

\section{KEY WORDS}

Cactaceae, Opuntioideae, Pterocactus australis, scientific expeditions, Typification.

\section{RESUMEN}

Se realiza la neotipificación de Opuntia australis F.A.C.Weber (basónimo de Pterocactus australis (F.A.C.Weber) Backeb.), gracias al hallazgo de manuscritos sobre esta especie de su autor y de una libreta con un dibujo a color del taxón, efectuado al tiempo de su primera colección. También se menciona una segunda libreta, complementaria, con una breve descripción de la planta y la expedición científica -poco documentada- que realizó el hallazgo en 1882, y a F. E. Schlumberger, quien la cultivó, colaborando con el autor. Una nota de Weber confirma que conoció la ilustración mencionada. Además, se encontró un ejemplar de herbario de la misma colección, que si bien no puede ser considerado material original ya que no consta que haya sido visto por el autor, es designado como epitipo.

\section{Palabras clave}

Cactaceae, expediciones científicas, Opuntioideae, Pterocactus australis, Tipificación.

\section{INTRODUCTION}

Opuntia australis was described by the French military medical doctor and amateur botanist Frédéric Albert Constantin Weber (1830-1903), who devoted his botanical research efforts basically to the Cactaceae family. He collaborated actively with the "Muséum National d'Histoire Naturelle, Phanérogamie", Paris, and contributed to the famous Dictionnaire d'Horticulture by Désiré Bois, published 1893-99.

In charge of the cactus family in Bois's Dictionnaire, Weber published the original description of Opuntia australis F.A.C.Weber in 1898. Although the description is short, it accurately describes the plant with diagnostic characters, and the original locality is given as "Patagonie, $d u 40^{\circ}$ au $50^{\circ}$ degré de latitude Sud, dans la Région magellanique, jusqu'au Sud du Rio Santa Cruz, où l'hiver est très rigoureux". ["Patagonia, from $40^{\text {th }}$ to $50^{\text {th }}$ degree of South latitude, in the Magellanic Region, down South of Santa Cruz River, where winter is very severe"]. Due to the concise style of the Bois's publication, neither type material 
nor name of the plant collector was mentioned. Weber's personal notes and letters received from Schlumberger about this plant have recently been found; among these documents, there is a reference to a colour drawing made at the time of the first discovery, which will be designated here as neotype. An herbarium specimen, which was collected at the same time as the drawing was done and living plants were collected, was also found, but there is no evidence that it was seen by Weber prior to the publication of $O$. australis. The various documents found are described and commented below.

\section{MATERIALS AND METHODS}

A research into Weber's documents at the main library of the Muséum National d'Histoire Naturelle in Paris led to the discovery of two documents at the botany library of the same institution, a sketchbook, and a notebook, which had been used by Weber. Additional research into their origins uncovered interesting historical facts about the expedition they had come from, and about other contemporary French expeditions in the same area, which can help to understand the origin of Patagonian plants described at the time. A research into the herbarium of the same institution $(\mathrm{P})$ also discovered a specimen of this species collected by the same expedition.

\section{Results}

Weber's notes

It is known that Weber had an active correspondence with many botanists and amateurs who were interested in cacti at that time (Catrix et al., 2019 and 2020). Some of these documents are held at the main library and the botany library of the Muséum National d'Histoire Naturelle, Paris (MNHN hereafter), and have been studied by one of us, J.-R. Catrix, who found Weber's personal notes and letters from Schlumberger, in an archive file referenced as "Per K 160", kept at the main library of MNHN.

Frédéric Émile Schlumberger (1823-1893) was a rich and gifted private plant grower who lived near Rouen in France. He grew and received plants on Weber's behalf, and prepared herbarium sheets exclusively for Weber. Their cooperation started in
1870 and stopped in 1893 when Schlumberger died (Catrix et al., 2020).

In a letter dated August 28, 1886, Schlumberger tells Weber: “... j'ai greffé la tête (la moitié) de votre opuntia australis;" [I have grafted the head (one half) of your opuntia australis;]. Later, in 1887 (August?): «... Votre fameux Opuntia Australis a émis sur le petit morceau que vous avez greffé une belle et vigoureuse pousse qui ne ressemble pas au petit chétif individu greffé. Elle a en ce moment $3 c$. $l$ sur $2 c$ diam et parait devoir faire une belle plante. J'avais greffé la tête l'année dernière, mais quoique bien reprise elle pousse mollement.» [... Your famous Opuntia Australis that you have grafted, has produced a nice and vigorous offset that is not as puny-looking as the graft. It is $3 \mathrm{~cm}$ long and 2 $\mathrm{cm}$ in diameter and it will probably produce a nice plant. Last year, I grafted the head, and although it has recovered well, it grows slowly]. The text that we have underlined in Schlumberger's citation and translation suggests that the plant had first been received and grafted by Weber and then given to Schlumberger. However, there is no indication of when and where Weber got the plant from.

Three personal notes by Weber deal with $O$. australis:

A) Undated:

"Op. australis. La fleur jaune paille sort tout à fait de l'extrémité de l'article dans lequel elle est comme immergée" [the straw-yellow flower emerges from the absolute tip of the article in which it seems to be immersed]

B) Beginning of undated text (probably from 188687); then, an addition dated 1889:

"Opuntia australis; greffé sur Op. subulata chez M. Schlumb. article cucumériforme forme de cornichon $8 \mathrm{~cm}$ long. $2^{1 / 2}$ largeur et épaisseur vert foncé avec teintes violacées - consistance molle, mamelonné - mamelons disposés en séries spirales à base large arrondie, portant à leur sommet ou plutôt sur leur page supérieure une aréole peu duveteuse blanchâtre, avec 12 ou 15 aiguillons blancs transparents rayonnants; de plus au sommet de l'aréole qques petits aiguillons très fins et courts, sétiformes, 2 aiguillons centraux, foliacés, recourbés, ascendants, cinérés ayant une certaine analogie avec ceux de l'Ech. capricornis. 1889 - L'article greffé devient très prolifère à la longue; les jeunes articles portent au sommet des folioles promptement caduques, longues de $1 \mathrm{~mm}$, 


\section{R. Kiesling et al. - Typification of Opuntia australis (Cactaceae)}

subulées, d'un vert \pm rubescent" [Opuntia australis; grafted on Op. subulata in Mr. Schlumberger's greenhouse. Cucumiform article, in the shape of a gherkin $8 \mathrm{~cm}$ long, $2 \frac{1}{2}$ wide and thick, dark green with purplish shade — soft consistency, tuberculated - tubercles in spiral series with a wide round base, with a whitish slightly fluffy areole at their tip or at their top part, with 12 or 15 white translucent radiating spines; at the top of the areole, moreover, there are a few very small and very thin spines, setiform, 2 central spines, foliaceous, bent, ascending, ash-colored, having some analogy with those of Ech. capricornis.

1889 - The grafted article becomes very proliferous in the long term; the top of young articles bears quickly deciduous leaflets, $1 \mathrm{~mm}$ long, subulate, green \pm rubescent.]

C) Undated (Fig. 1):

“Mission de Santa Cruz de Patagonie. L'aviso le Volage commandé par M' Ingous lieutenant de vaisseau. Croquis des plantes collectionnées par le docteur Couteaud, exécutés par le $2^{e} M^{\text {ire }} M^{\text {cien }}$ Heimsch par ordre du commandant. Planche 45 Cereus patagonicus en fleur, colorié. Pl. 46 Op. australis en fl., color." [Mission of Santa Cruz of Patagonia. The escort boat Le Volage, commanded by first officer Ingous. Sketches of the plants collected by doctor Couteaud, and drawn by the $2^{\text {nd }}$ chief mechanic Heimsch by the captain's order. Plate 45 flowering Cereus patagonicus, colored. Plate 46 flowering $O p$. australis, colored.]

\section{The sketchbook}

Weber's note $\mathrm{C}$ above (Fig. 1) refers to the documents illustrated in Figures 2 and 3, found at the botany library of MNHN under reference Per $\mathrm{K} 42$. The two drawings are parts of a sketchbook (Heimsch, 1882) with 77 colored drawings of plants. The text on the cover page indicates that they were drawn by the $2^{\text {nd }}$ chief mechanic Heimsch of the ship "Le Volage" (Fig. 2), under the supervision of the ship's medical doctor, Dr Couteaud, who collected the plants, and of the captain, M. Ingouf. The drawings are all numbered and the scale is sometimes mentioned by a meticulous hand, probably Heimsch's, while some plates also bear names of plants, written with a pencil, often with question marks, by another anonymous hand. No date is provided in this sketchbook.
The sketchbook is supplemented by a notebook with a similar title on the cover: "Mission du Santa Cruz de Patagonie - Aviso le Volage commandé par Mr. Ingouf Lieut de Vau - Rapport du Docteur Couteaud sur la flore de Santa Cruz" [Mission of Santa Cruz of Patagonia - Escort boat Le Volage commanded by Mr. Ingouf, first officer - Doctor Couteaud's report about Santa Cruz flora] which provides descriptions for all the plants drawn in the sketchbook, classed by families. A foreword from the author explains: "Les trois mois que le Volage a passés à Santa Cruz ont été mis à profit pour recueillir les plantes et les faire dessiner. La saison était on ne peut plus favorable puisque le printemps allait commencer. Malheureusement notre séjour ne s'est pas prolongé suffisamment pour nous permettre de faire dessiner toutes les plantes. Néanmoins on peut voir par les descriptions sommaires ci-jointes, destinées à compléter les

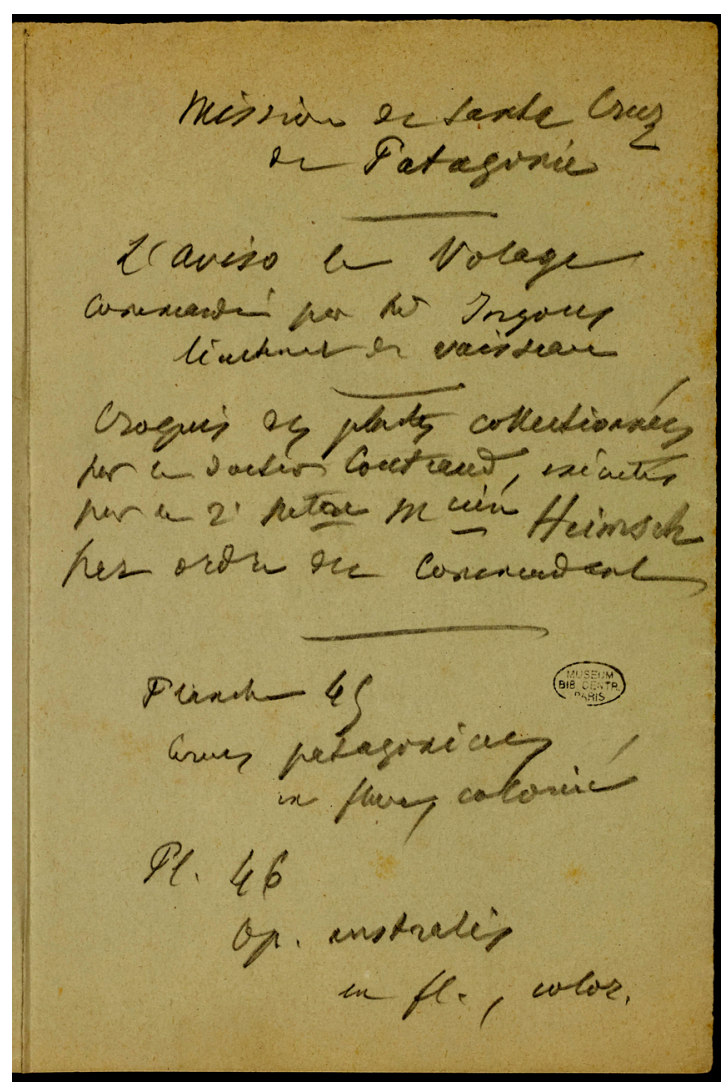

Fig. 1. Weber's handwritten notes about the sketchbook that shows the plate of Opuntia australis. (C) Muséum National d'Histoire Naturelle, June 2020. 


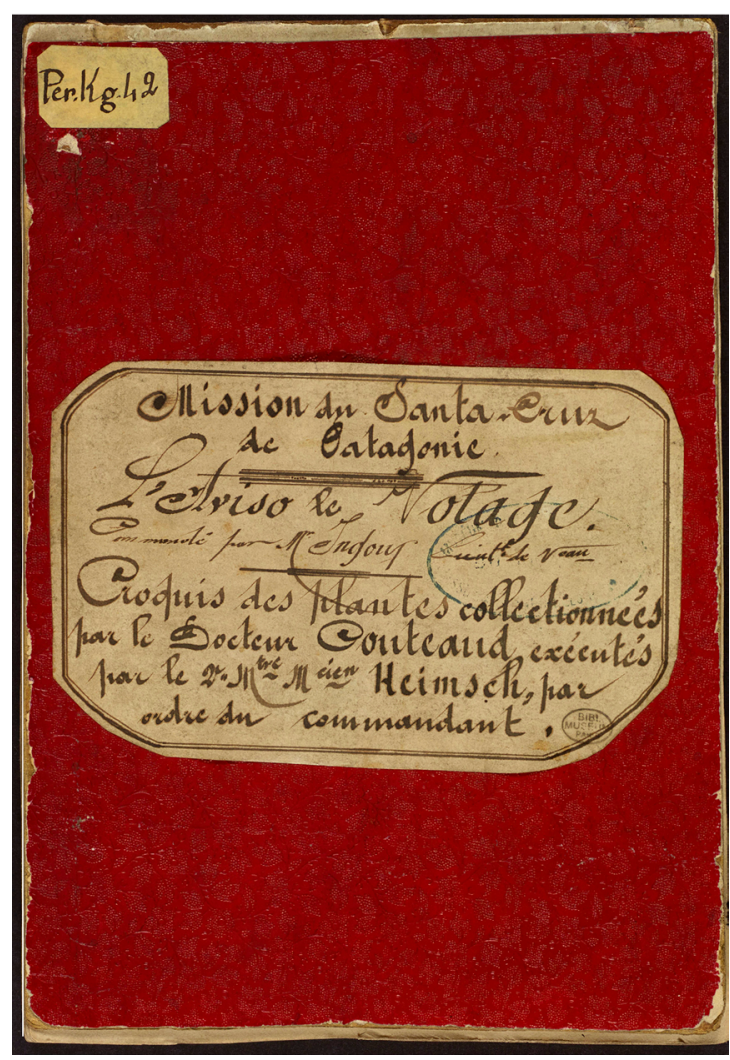

Fig. 2. Front cover of the sketchbook with the plates drawn by J.F. Heimsch. (C) Muséum National d'Histoire Naturelle, June 2020.

dessins, que la Flore de cette partie de la Patagonie est suffisamment variée. Beaucoup de plantes qui ne figurent pas dans les dessins, notamment les plantes marines, ont été recueillies dans l'herbier dressé en collaboration avec M. Lebrun." ["The three months spent in Santa Cruz by the Volage were used to collect plants and have them drawn. The season was extremely favorable, as spring was beginning. Unfortunately, our stay wasn't long enough to allow us to have all plants drawn. Nevertheless, from the short descriptions, meant to supplement the drawings, it can be seen that the flora of this part of Patagonia is rather varied. A lot of plants that do not appear among the drawings, notably marine plants, have been gathered in the herbarium processed in collaboration with Mr. Lebrun. ....]"

From the descriptions, the three months spent in Santa Cruz were October to December 1882. The plants collected by Lebrun ( 96 specimens) and Couteaud (126 specimens) did arrive in the MNHN

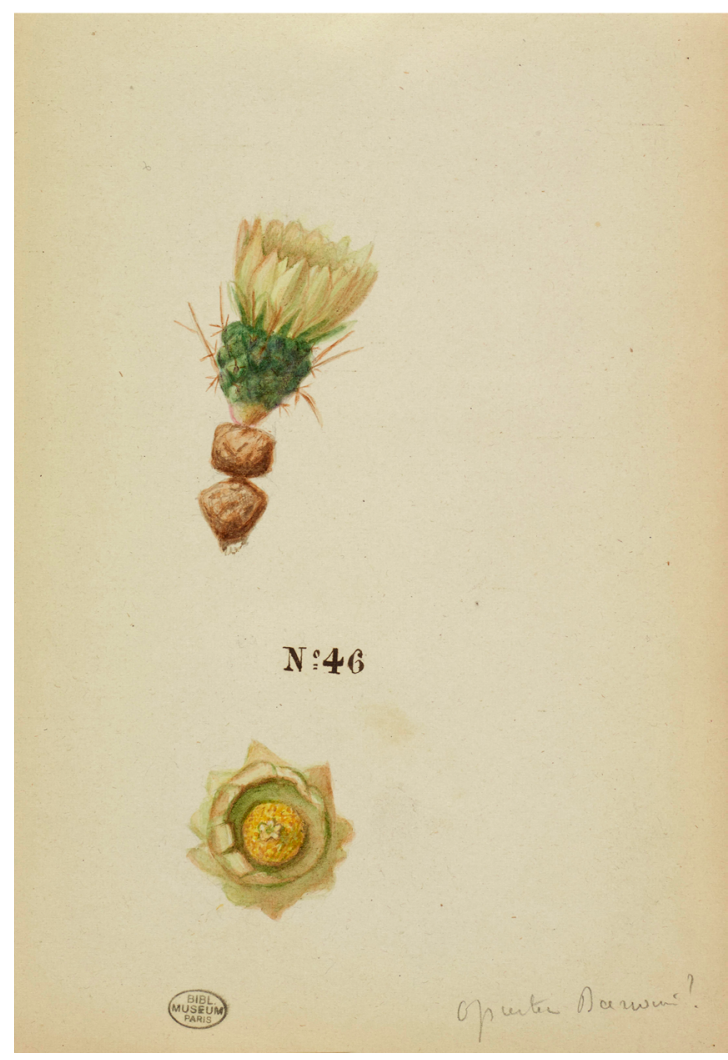

Fig. 3. Neotype of Opuntia australis, Plate 46 of the booklet. The tentative name "Opuntia Darwini ?" is anonymous. J.F. Heimsch, (C) Muséum National d'Histoire Naturelle, June 2020.

herbarium (P) in February 1883, as recorded in the entries of the herbarium's logbook.

In the sketchbook, the Cactaceae are represented by plates 45 and 46 only, with the tentative name "Opuntia darwini?" for both. In the notebook, Dr. Couteaud's description of plate 45 (Cereus patagonicus) starts with the name "Cactus opuntia?"; the description of the plant of plate 46 (Opuntia australis) is transcribed and translated in the appendix.

Note $\mathrm{C}$, which reproduces the text of the sketchbook cover (Fig. 1), proves that Weber did see and study this booklet, even though he wrote "Ingous" instead of "Ingouf", surely confusing the " $f$ " with a long "s". It is not known whether Weber actually saw Dr. Couteaud's notebook. Fig. 1 shows that he gave the name Cereus patagonicus to the plant of plate 45 . That species name was published by C. L. Spegazzini (1858-1926) who attributed it 


\section{R. Kiesling et al. - Typification of Opuntia australis (Cactaceae)}

to Weber ("Cereus patagonicus Weber (in litt.)"). Then, Spegazzini should be considered the author who cited other plant material, but he had never seen plate 45 , which therefore cannot be the type for $C$. patagonicus. Weber also gave the name " $O$. australis" to the plant of plate 46 (Fig. 3) that was erroneously named "Opuntia Darwini?" by an anonymous person. It is clearly the currently named Pterocactus australis (F.A.C.Weber) Backeb.

\section{The Volage and its crew}

The sketchbook and notebook originated from the 1882-1883 mission embarked on the escort-ship Le Volage, organized to observe an astronomical event, the transit of Venus in front of the solar disc in December 1882, which was useful to determine the sun-Earth distance. Various expeditions were sent to the south hemisphere on this occasion by several countries. The French government sent three astronomical missions to different parts of Patagonia, meant to embark on ships that were already in Montevideo, like the Volage. The Volage's scientific team comprised EdouardAdolphe Lebrun, a collection technician from the MNHN zoology chair, sent as a naturalist, along with the astronomer and naval officer GeorgesErnest Fleuriais (1840-1895) and his aides. He had the help of Dr. Pierre Benjamin Couteaud (18551940), the ship's medical doctor, who collected not only plants but also geological specimens (now kept at MNHN). The second chief mechanic, Jules Frédéric Heimsch (1859-1920) had artistic talents that were not limited to plants: his drawings of fishes are mentioned in the publication made by the Mission scientifique du Cap-Horn (Milne-Edwards, et al. 1891).

Six scientists formed the Mission scientifique $d u$ Cap-Horn, aimed at studying the polar regions on the ship La Romanche, captained by LouisFerdinand Martial; they published several volumes of their findings (Martial 1888), one of them on botany, mainly cryptogamic plants, authored by Paul Hariot, Emile Bescherelle, Adrien Franchet, and Paul Petit (Hariot et al. 1889).

The Romanche and the Volage met in Montevideo in August 1882 - where was also the French boat Labourdonnais -, and probably met again later. In fact, Lebrun left the Volage rather quickly, traveled from Santa Cruz to Punta Arenas, and then joined the Romanche in February 1883 (Perrier, 1905).
This explains why Heimsch's fish drawings, as well as some bird specimens collected by the Volage's crew, are mentioned in the publication of the Mission scientifique du Cap-Horn.

This is not the case for the botanical collections made by the Volage's team: the botany volume of the Mission scientifique du Cap-Horn does not even mention any plant collected by either Lebrun or Couteaud.

The scientific results of the Volage expedition were never published; it is mentioned mainly in the general press, such as the March $16^{\text {th }}, 1883$ issue of the French newspaper "Le Soleil" (Fig. 4): “M. Ingouff ... accompagné... d'un naturaliste du Muséum, M. Le Brun ... avait remonté le Santa-Cruz vers la cordillière... Cette expedition... a rapporté un nombre considerable de fossiles" (see full text and translation in the appendix).

The drawings by J. F. Heimsch and the descriptions by Dr. Couteaud (1882) are a precious testimony of the botanical collections made by the Volage expedition and must come as a supplement to the contemporary publication of the Mission scientifique du Cap-Horn for the discovery of the flora of Patagonia.

Although the other botanical collections made by the Volage expedition have not yet been found at the $\mathrm{P}$ herbarium, F. Tessier was able to find one herbarium sheet of Cactaceae that can be linked to it (P04594032, available in http://coldb.mnhn. $\mathrm{fr} /$ catalognumber/mnhn/p/p04594032); the label clearly states that the material was received on March 25, 1883 from Patagonia, Santa-Cruz, Dr. Couteaud (written Couteau). It contains two pieces of plant material, misidentified as the Peruvian cactus species Echinocactus aurantiacus Vaupel. Since the only cacti collected by Couteaud were $O$. australis and C. patagonicus, this material must be pieces of one or both plants. The piece of dry material on the left of the herbarium sheet is clearly a flower of $O$. australis, whereas the piece on the right - a single flower - can be from the Cereus patagonicus collected at the same time, but we were not able to identify it with full certainty from the picture.

\section{Typification}

Considering that:

1) There is no type material mentioned in the original description by Weber, and that he never 


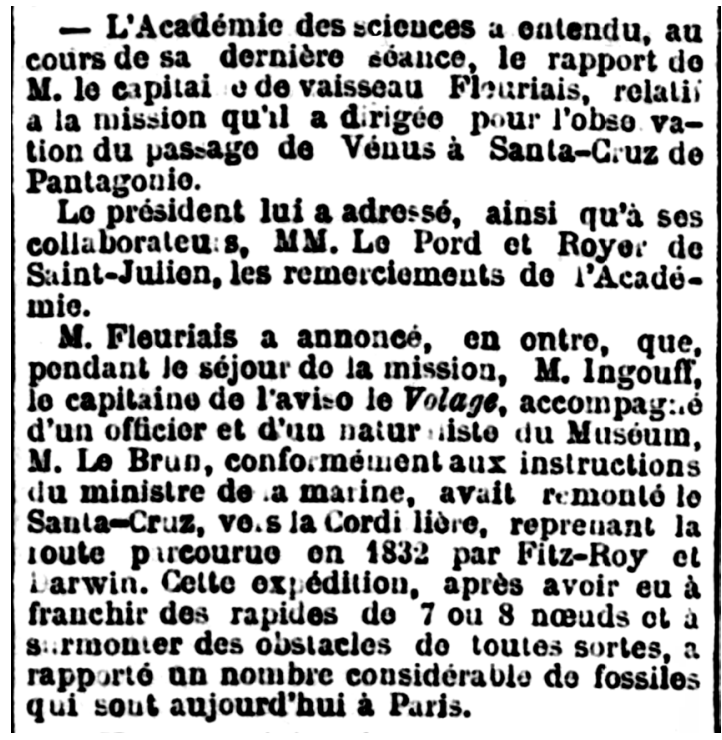

Fig. 4. Excerpt of the newspaper "Le Soleil", March 16,1883 , under "Nouvelles diverses" indicating the expedition of the escort boat "Volage" along the Santa Cruz river.

mentioned the preserved herbarium material of $O$. australis in his notes, nor in any publication.

2) Although we cannot rule out with certainty that plate 46 was seen by Weber prior to the description of $O$. australis and would therefore be "original material" in the sense of Art. 9.4(a) (Turland et al., 2018), and considering the fact that he used living plant material for the description, we prefer to designate the plate as Neotype.

3) The herbarium specimen P04594032, left part, can also be "original material", but having no evidence that it was seen by Weber, we prefer to designate plate 46 as Neotype.

4) Since a type should preferably be a specimen, we are designating the mentioned Couteaud's specimen as Epitype, due to its being part of the first collection.

Pterocactus australis (F.A.C. Weber) Backeb., Desert P1. Life 22(10): 17. 1950. Opuntia australis F. A. C. Weber, Dict. Hort. [Bois] 2: 896. 1898. NEOTYPE (here designated): plate 46 in the sketchbook "Mission de Santa Cruz de Patagonie. L'aviso le Volage commandé par $\mathrm{M}^{\mathrm{r}}$ Ingous lieutenant de vaisseau. Croquis des plantes collectionnées par le docteur Couteaud, exécutés par le $2^{\mathrm{e}} \mathrm{M}^{\text {tre }} \mathrm{M}^{\text {cien }}$ Heimsch par ordre du commandant".
Botany Library, Direction des Bibliothèques et de la Documentation, Muséum National d'Histoire Naturelle, Paris (MNHN), reference Per K 42. Original manuscript, unpublished (Fig. 3). EPITYPE: Couteaud specimen, left piece, collected by Couteaud ("Patagonie. S ta $^{\text {ta }}$ Cruz. M. le Dr. Couteau. Reçu le 25 mars 1883"; P 04594032!). Fig. 5. Available at http://coldb.mnhn.fr/catalognumber/ $\mathrm{mnhn} / \mathrm{p} / \mathrm{p} 04594032$, stored under the name Echinocactus aurantiacus. Accessed 25 Feb 2021.

Distribution. It is distributed over a nearly continuous strip of land along the Atlantic coast from N of Río Negro province to Santa Cruz province, and across the whole Patagonian plateau, mostly near the rivers, lakes, or slightly humid soils. It has recently been found in the Chilean territory (Saldivia \& Rojas, 2008) at Chile Chico, Aysen Region, ca. $46^{\circ} 36^{\prime} \mathrm{S}, 71^{\circ} 30^{\prime} \mathrm{W}$. The extreme Argentinean localities recorded are, in the NW: Neuquén, Zapala district, Laguna Blanca, ca. $39^{\circ} \mathrm{S}, 70^{\circ} 20^{\prime} \mathrm{W}$; in the NE: Río Negro, San Antonio district: Sierra Grande; ca. $41^{\circ} 40^{\prime} \mathrm{S} 65^{\circ} 22^{\prime} \mathrm{W}$; in the SW: Santa Cruz, Calafate district, La Leona ca. $50^{\circ} \mathrm{S}, 72^{\circ} \mathrm{W}$; in the SE: Santa Cuz, Río Santa Cruz, Corpen Aike district, Cte. L. Piedrabuena, ca. $50^{\circ} \mathrm{S}, 68^{\circ} 45^{\prime} \mathrm{W}$.

Although some populations have strong and thick erect central spines, most of them are thin, flat, paperlike, and this makes this Pterocactus be confused with the grasses among which it frequently grows (Fig. 6).

\section{FINAL REMARKS}

The description was supplemented by a Weber's posthumous article written and published by Roland Gosselin (1904). It is essentially based on Weber's notes and on the description in Bois's dictionary. Some details about the flower and seeds are additions from Roland-Gosselin.

In his description, Weber mentioned that $O$. australis spreads over a range from 40 to $50^{\circ} \mathrm{S}$. The reference to $40^{\circ}$ is very plausibly due to a list of plants found among Weber's notes and sent to him by the Swedish botanist P. H. K. Dusén, who collected these plants at $39^{\circ} \mathrm{S}$, near the Rio Negro; he collected in Patagonia from 1895 to 1897 . On the other hand, the mention of "to $50^{\circ} \mathrm{S}$ " most probably refers to the Volage expedition. 


\section{R. Kiesling et al. - Typification of Opuntia australis (Cactaceae)}

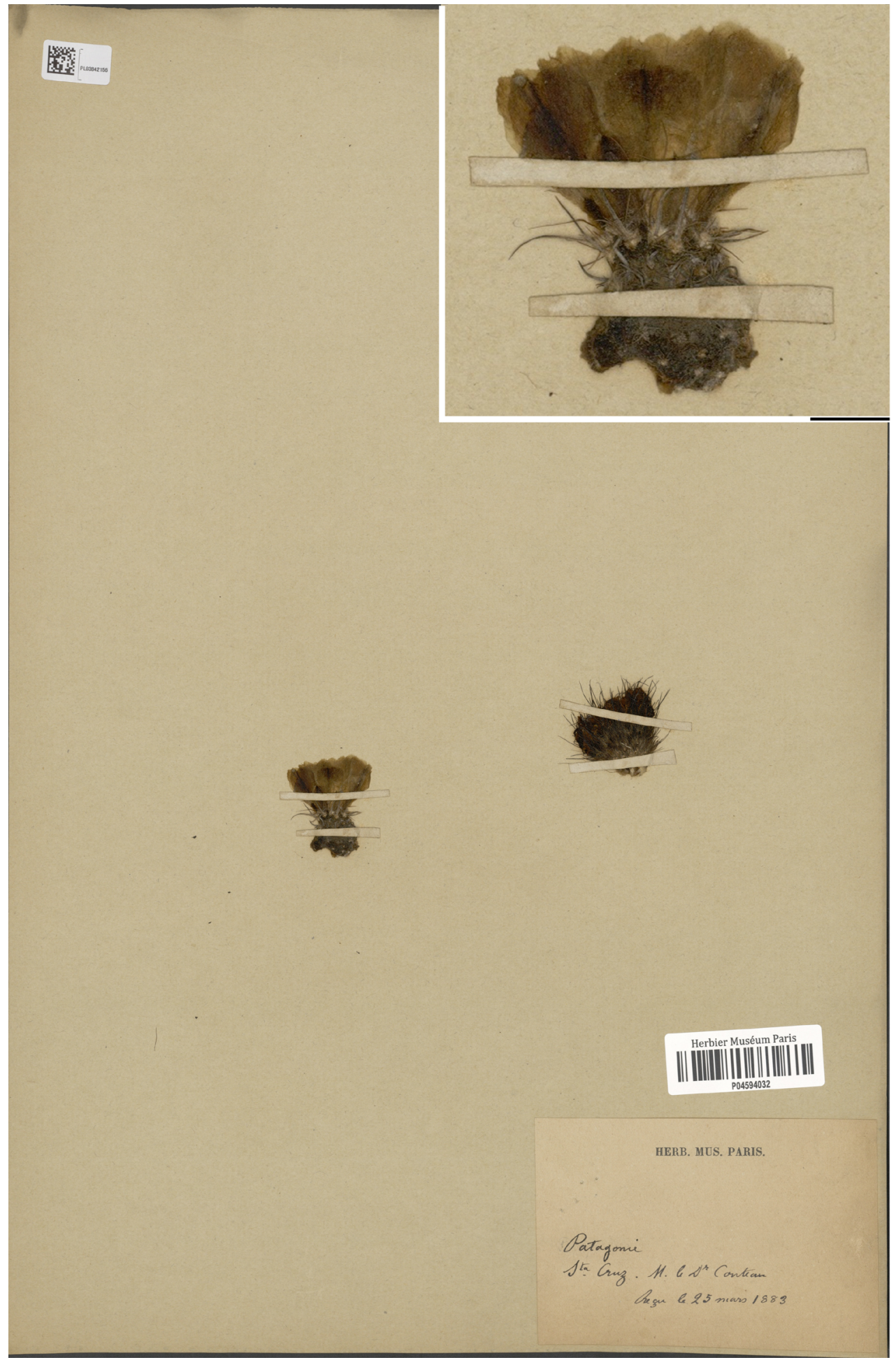

Fig. 5. Epitype of Pterocactus australis (Opuntia australis) deposited in Herbarium Paris, @ Muséum National d'Histoire Naturelle ( $P$ barcode 04594032 ). In the right apical square, the portion of the plant mounted on the left, which is here selected as epitype (scale bar $1 \mathrm{~cm}$ ). 

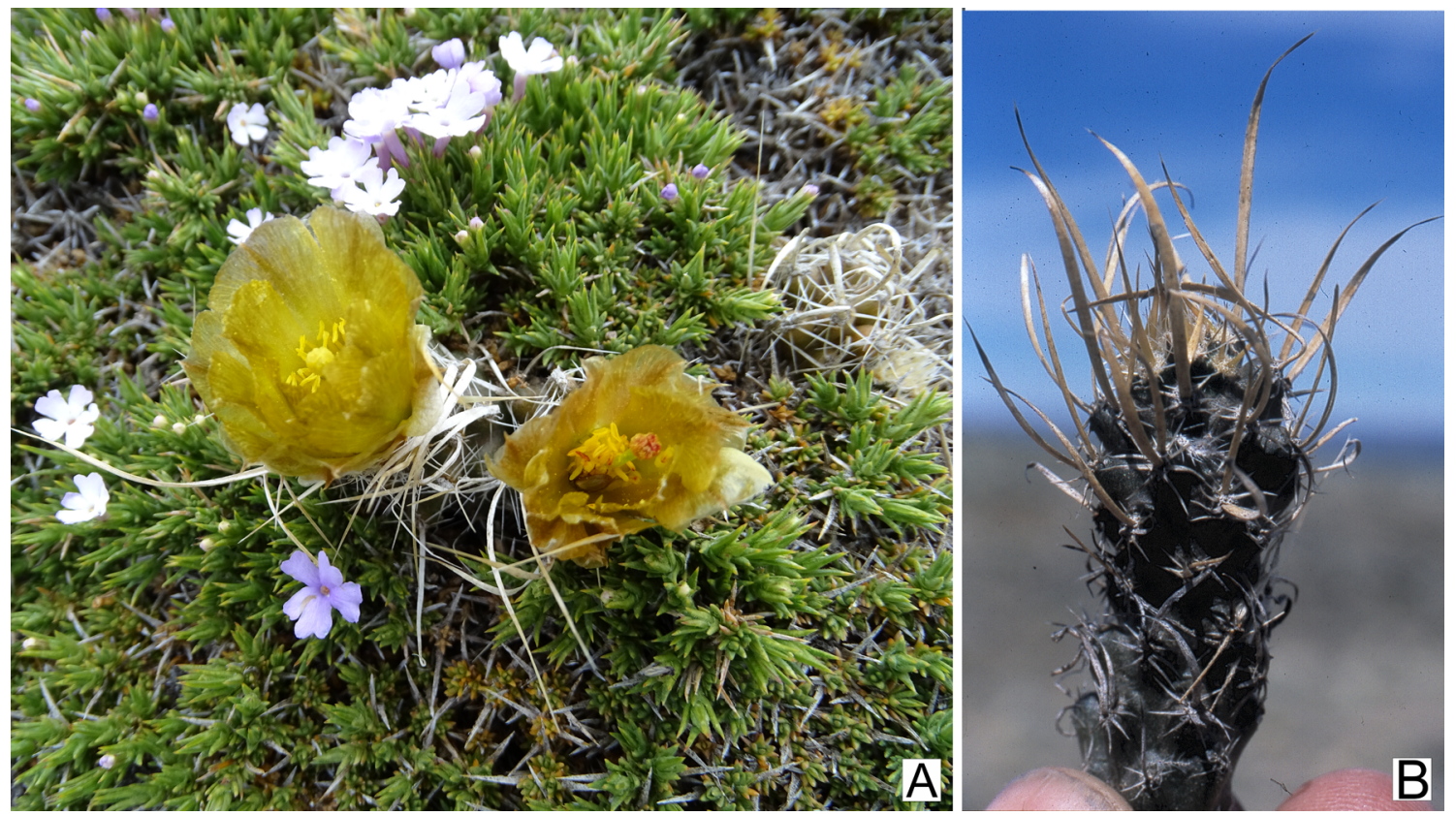

Fig. 6. Pterocactus australis (Opuntia australis). A: Specimen in flower between cushion-shaped Verbenaceae plants, in Laguna Blanca, Neuquén province. B: Apical portion of the stem, with thin, flat, whitish and paper-like spines. Photographs, A: by Marcela Ferreira. B: by Roberto Kiesling.

\section{AUTHORS' CONTRIBUTIONS}

JRC searched, analysed, and put in order archive documents from Weber. FT located the sketchbook, the notebook, and the herbarium sheet, and collected information about the historical context of the expedition. DS coordinated the work and shared information with RK, who investigated the nomenclatural status of plate 46 and prepared the typification. All authors participated in writing the article.

\section{ACKNOWLedgements}

To the main library of the Muséum National d'Histoire Naturelle, Paris. To Mr. J.-C. Rouxel, webmaster of "Parcours de vie dans la Royale" (http:// ecole.nav.traditions.free.fr), who provided data on J.A. Ingouf, P.B. Couteaud, and J.F. Heimsch. To Dr. Detlev Metzing, who revised the note and corrected our nomenclatural considerations. To Nelly Horak for the improvement of our poor English style. Also to the two anonymous reviewers and the editor for their valuable observations.

\section{Appendix}

1-Transcription of the description of the plant of plate 46 written by Dr. Couteaud:

Fig. 46

Cactus beaucoup plus petit que le précédent; $0^{m} .04$ ou $0^{m} .05$ de $h^{\text {auteur }}$. La racine présente 2 ou 3 renflements tubéreux. Fleurs jaunâtres, comme satinées. Irritabilité extrême des étamines; au moindre attouchement elles convergent vers le pistil.

[Cactus much smaller than the previous one; $0^{\mathrm{m}} .04$ or $0^{\mathrm{m}} .05$ tall. The root shows 2 or 3 tuberous bulges. Flower yellowish, almost silky. Stamens extremely sensitive; at the slightest touch, they converge towards the style.]

\section{2-Translation of "Le Soleil" newspaper excerpt}

(Fig. 4):

At the last meeting of the academy of sciences, Captain Fleuriais gave a report about the expedition devoted to the observation of Venus transit, in Santa Cruz of Patagonia.

The chairman congratulated Captain Fleuriais and his collaborators Mrs. Le Pord and Royer de Saint Julien. 


\section{R. Kiesling et al. - Typification of Opuntia australis (Cactaceae)}

Moreover, Mr. Fleuriais announced that during the expedition, M. Ingouff, Captain of the escort boat "Volage", together with an officer and a nature scientist of the Muséum, Mr. Le Brun, in accordance with the instructions of the navy Minister, had gone along the Santa Cruz river back to the cordillera, and followed the trail of Fitz-Roy and Darwin in 1832. This expedition, after crossing rapids of 7 to 8 knots and clearing obstacles of any kind, gathered a huge amount of fossils that are now in Paris.

\section{BiBLIOGRAPHY}

BOIS, D. 1893-1899. Dictionnaire d'Horticulture. Klincksieck, Paris.

CATRIX, J.-R., R. KIESLING \& D. SCHWEICH. 2019. Frédéric Albert Constantin Weber. Travaux consacrés aux Cactus et Agaves I: publications et correspondance avec Engelmann. [online]. Available at: https:/www.cactuspro.com/biblio/ en:catrixkieslingschweich

CATRIX, J.-R., R. KIESLING \& D. SCHWEICH. 2020. Frédéric Albert Constantin Weber. Travaux consacrés aux Cactus et Agaves II: Notes de travail Correspondance diverse [online]. Available at: https:// www.cactuspro.com/biblio/en:catrixkieslingschweich

COUTEAUD, P. 1882. Rapport du Docteur Couteaud sur la flore de Santa Cruz. Mission de Santa Cruz de Patagonie. L'aviso le Volage commandé par Mr Ingouf lieutenant de vaisseau. Per. K 42, Botanical Library of the Muséum national d'Histoire naturelle, Paris. Location: Per. K 42. Original manuscript, unpublished.

HEIMSCH, J. F. 1882. Croquis des plantes collectionnées par le docteur Couteaud, exécutés par le $2^{e} M^{\text {re }} M^{\text {cien }}$ Heimsch par ordre du commandant. Mission de Santa Cruz de Patagonie. L'aviso le Volage commandé par Mr Ingouf lieutenant de vaisseau. Botanical Library of the Muséum national d'Histoire naturelle, Paris. Location: Per. K 42. Original manuscript, unpublished.

MARTIAL, L. F. 1888. Mission Scientifique du Cap Horn 1882-1883. Tome I. Histoire du voyage. GauthierVillars. Paris [online]. Available at: https://gallica.bnf. fr/ark:/12148/bpt6k853855r?rk=42918;4

MILNE EDWARDS, A., E. OUSTALET \& L. VAILLANT. 1891. Mission scientifique du Cap Horn, 1882-1883. Tome VI, Zoologie, le partie. Gauthier-Villars, Paris [online]. Available at: https://gallica.bnf.fr/ ark:/12148/bpt6k9626281t?rk=107296;4
HARIOT, P., P. PETIT, J. MULLER D'ARGOVIE, et al. 1889. Mission Scientifique du Cap Horn 1882-1883. Tome V. Botanique. Gauthier-Villars, Paris [online]. Available at: https:/gallica.bnf.fr/ ark:/12148/bpt6k8539505?rk=21459;2

PERRIER, R. 1905. Holothuries antarctiques du Muséum national d'Histoire naturelle. Annales des Sciences naturelles, IXe série, p. 1-146.

ROLAND-GOSSELIN, M. R. 1904. Euvres posthumes de M. le Dr Weber, médecin inspecteur de l'armée. Bulletin Du Muséum d'Histoire Naturelle 6: 382-389 [online]. Available at: https://www.cactuspro.com/ biblio/en:catrixkieslingschweich

SALDIVIA, P. \& ROJAS, G. 2008. Nuevos Registros y Antecedentes de la Familia Cactaceae para Chile en la Region de Aisen. Gayana Bot. 65: 198-208.

TURLAND, N. J., J. H. WIERSEMA, F. R. BARRIE, W. GREUTER, D. L. HAWKSWORTH, P. S. HERENDEEN, S. KNAPP, W.-H. KUSBER, D.-Z. LI, K. MARHOLD, T. W. MAY, J. MCNEILL, A. M. MONRO, J. PRADO, M. J. PRICE \& G. F. SMITH (eds.) 2018. International Code of Nomenclature for algae, fungi, and plants (Shenzhen Code) adopted by the Nineteenth International Botanical Congress Shenzhen, China, July 2017. Regnum Vegetabile 159. Koeltz Botanical Books, Glashütten. https://doi. org/10.12705/Code. 2018

WEBER, F. A. C. 1898. Opuntia. In: BOIS, D. G. Dict. Hort 2: 892-899. Klincksieck, Ed. Paris.

\section{Additional documents}

In order to help other researchers, below we give some sources of more information about the expedition and its participants:

Documents about HEIMSCH, J. F. Archives nationales, Légion d'honneur database: http://www2. culture.gouv.fr/LH/LH087/PG/FRDAFAN83 OL1277080v016.htm

About the Captain J.A. INGOUF: http://ecole.nav. traditions.free.fr/officiers_ingouf_jules.htm

About P.B.COUTEAUD: http://ecole.nav.traditions.free. fr/officiers_couteaud_pierre.htm

About A.E. LEBRUN: FLEURIAIS G., 1883. Mission de Santa-Cruz de Patagonie. Comptes rendus hebdomadaires des séances de l'Académie des Sciences 97: 392-401. https://vt2004.imcce.fr/ CDs/CD-VT-histoire/telech-txt-image/GALLICA/ 
Bol. Soc. Argent. Bot. 56 (1) 2021

MEMOIRESACADEMIE/tome97/Memoires-acadtome97-p353-443/html/40.html

Archival institutions, which we have not visited, keep some documents from the Volage expedition:

- Journaux de bord du Volage, Archives du Service Historique de la Défense, Paris. Location: MR 3 C 192.
- Archives nationales: Le Volage: Sondes par les lieutenants de vaisseau Ingouf, Lartigue, Tracou et Pradier dans le rio Santa-Cruz, Patagonie. 1882-1883, Paris. Service hydrographique de la Marine. Location: MAR/5JJ/263

- American Philosophical Society Library, Passage de Venus, Mission de Santa Cruz (Patagonie), Photograph Album, Philadelphia, EE.UU. Location: Mss. B.F63. 